Thus, the task of assessing the significance of characteristics in the analysis of student learning data in the Moodle distance learning system was solved. The assumption that the weights of the features characterize the level of significance of each investigated feature is substantiated. The most significant features that affect the quality of the introduction of distance learning are highlighted.

Key words: multi-layer neural network, many features, informative, distance learning.

Отримано: 28.11.2018

UDC 004.042;004.5

DOI: $10.32626 / 2308-5916.2018-18.110-115$

I. E. Furtat*, Ph. D., Associate Professor, Yu. O. Furtat**, Ph. D.

* National Technical University of Ukraine «Igor Sikorsky Kyiv

Polytechnic Institute», Kyiv,

**Pukhov Institute for Modeling in Energy Engineering, NASU, Kyiv

\title{
BUILDING USER INTERFACE AND DOMAIN MODELS BASED ON THE USERS' COGNITIVE CHARACTERISTICS AND WORK PROCESS SPECIFICS
}

The principles of construction and management of the automated systems' UI (responsible for a form of presenting information to the user) and domain (responsible for a structure of presenting information to the user) models are considered as components of the complex of means for managing user's informational interaction with the automated system management means, adapting this interaction to the user's individual characteristics and work process specifics.

Key words: informational interaction, adaptation, domain model, user's cognitive characteristics.

Introduction. User interaction with information in the automated system is conducted through system generating an information flow [13] that the user perceives and processes (fig. 1).

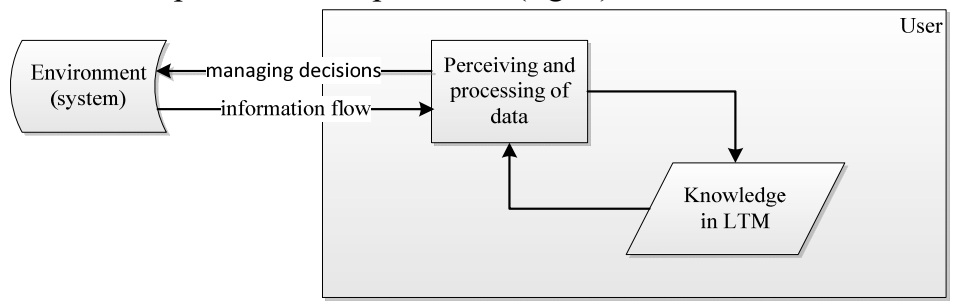

Fig. 1. User-system informational interaction scheme 
Based on received information users make some decisions using their own skills and knowledge in long-term memory (LTM), that are transmitted via the user interface to the system, changing its state. Set of UI management elements is determined by the specific workflow tasks and user's characteristics. The flow of information from the system is formed with regard to the user's requests to the system, current workflow step and user interface's output elements through which data will be displayed for the perception and processing of the user. Each of the participants and the elements of information exchange has a number of features, by managing which the process can be adapted to the specific user and the specific situation in the workflow.

Information flow parameters and adaptation. Information flow $I$ from the system can be described as a set of parameters:

$$
I=\langle T, F, C, D\rangle,
$$

$T$ - pace of presentation, $F$ - data format, $C$ - information complexity, its connectivity to other blocks of data, $D$ - transmitted data.

Pace of presentation is a qualitative characteristic that can be set to $T=\langle\langle$ low», «medium», «high»>. The pace of presenting information in automated systems can be managed in non-critical situations by changing the flow intensity depending on the acceptable level of information load. The users' optimal rate is determined by their ability to respond quickly to data from the system, and the current level of fatigue and concentration.

Data format $F$ can be «text», «graphic», «spreadsheet», «audio», «mixed». In general, data format is defined by the user interface's output elements, yet if there is a possibility of changing this set according to users' needs and demands presentation format can also be adapted to the users' characteristics (their cognitive portraits).

The complexity of information - a complex value, which takes into account the links between data blocks in the domain model, the data links amount involved in presenting current portion of data, its overlapping with the user's knowledge model

$$
K M=\left\langle K_{i},\left\langle c^{j}\right\rangle_{i}\right\rangle, i, j=\overline{1, n}
$$

$K_{i}, i=\overline{1, n}$ - domain data blocks, $\left\langle c^{j}\right\rangle_{i}, i=\overline{1, n}, j=\overline{1, n}, j \neq i-i^{\text {th }}$ data block's connection vector.

Parameter $D$ is a portion of data transferred to the user in the particular workflow episode. This portion may correspond to one domain data block or it may consist of a set of blocks or a part of a single block, depending on the user-system interaction script.

In most modern automated systems user-system interaction is defined by the following algorithm (fig. 2). 


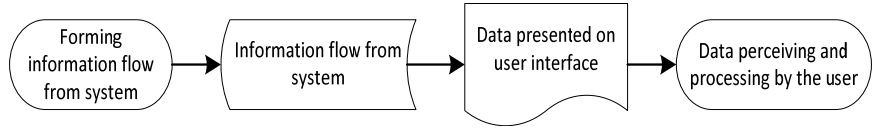

Fig. 2. User-system information interaction

To perform information exchange adaptation the algorithm in fig. 1 should be modified to allow consideration of specific users' and workflows' characteristics.

As adaptation criterion the users' cognitive portraits are considered, as adaptation object - data presentation form and pace (information flow characteristics).

If the user-system informational interaction process's adaptation and personalization is considered as controlling parameters of an information flow (1), we obtain a modified information exchange, shown in fig. 3 .

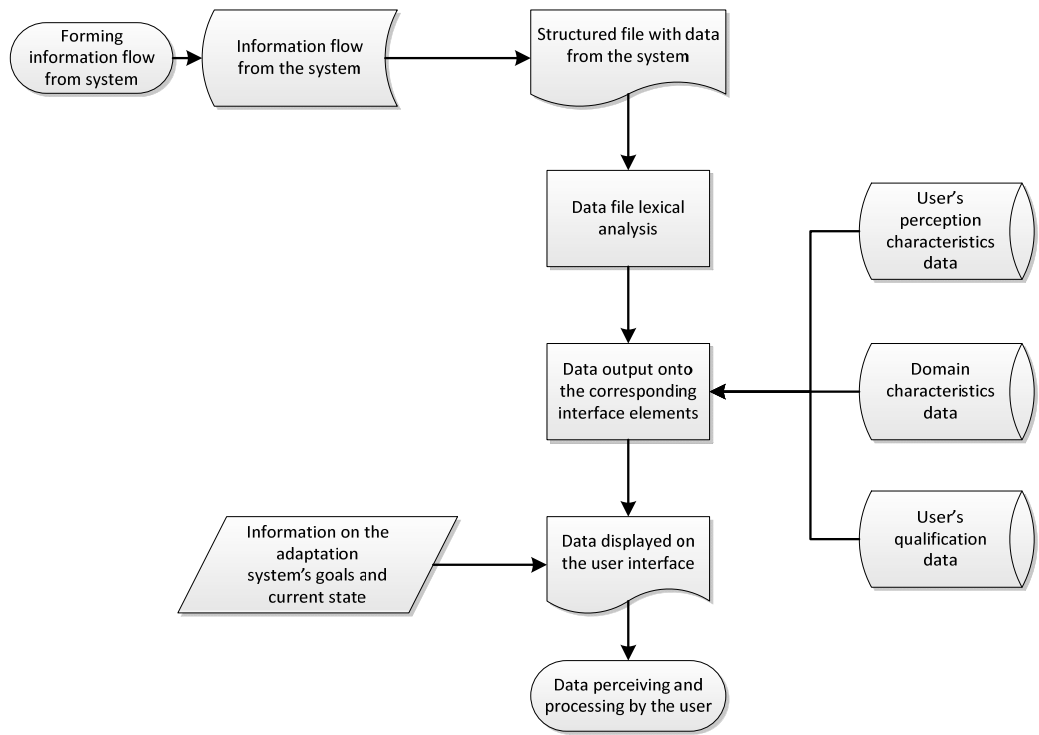

Fig. 3. Adapted user-system information interaction

Information exchange adaptation and personalizing is performed at the stage of information flow's forming (managing parameters $T$ and $C$ of model (1)) and at the stage of data output through user interface (managing parameter $F$ ). Information flow's parameter $D$ depends on the specifics of the overall workflow, and on the current users' specific goals.

Managing data output through personalized user interface. User interface in automated systems is considered as a set of elements $U I=\left\langle E_{i}\right\rangle, i=\overline{1, n}$, each output element 


$$
E_{i}=\left\langle\langle x, y\rangle_{i}^{j}, T_{i}, c_{i}\right\rangle, j=\overline{1, m}
$$

$\langle x, y\rangle_{i}^{j}-$ output element's corner coordinates; $T_{i}-i^{\text {th }}$ element's output type; $c_{i}-i^{\text {th }}$ element's weight (importance) for the user.

The set of values of $T_{i}$ in model (3) coincides with the set of values of parameter $F$ in model (1), and it is the type of available output elements which determines the preferred output data format on the information flow's formation stage.

Output element's weight is defined by the workflow's specifics. Critical elements display information, loos of which to disruption of the workflow or inability for the user to correctly process information from the system.

Managing output elements' position and type allows creating personalized user interface for adapting the user-system information interaction. Critical output elements output must be present in the user interface, regardless of its adaptation.

Desired output element types are defined by the users' cognitive portraits' characteristics.

Cognitive portrait is a set of user characteristics.

$$
C P=\left\langle\left\langle\operatorname{Cog}_{i}\right\rangle,\left\langle P P_{j}\right\rangle,\left\langle\operatorname{Int}_{k}\right\rangle\right\rangle, i=\overline{1, m}, j=\overline{1, n}, k=\overline{1, p},
$$

$\operatorname{Cog} n_{i}-\operatorname{cognitive}$ users' characteristics; $P P_{j}-$ physiological characteristics; Int $_{k}$ - intellectual characteristics.

Cognitive portrait's characteristics define optimal for on-screen data presentation number, type and relative position of user interface output elements.

Using domain knowledge model to manage information storage form. To enable further flexible information interaction adaptation it is advisable to manage not only presentation form, but the pace and intensity of information flow. This requires the ability to manage blocks of information, knowledge system organization, personalized learning programs.

Existing knowledge communications systems can be characterized by four basic components: expert domain knowledge (domain model); user model; expert knowledge of teaching method (interaction script); usersystem interface.

Knowledge model (2) performs a dual function. On the one hand it is a source of domain knowledge that is provided to the user in portions, on the other - it sets the desired standard for the users' current knowledge level evaluation. Domain model has an important place in the process of scripting user interaction with the information and in the management of information flow characteristics within decision-making metascript in automated systems. In automated learning systems knowledge models are connected to the discipline's lesson plan, which 
provides both the knowledge blocks' contents and the order in which the users access these bloks.

User model is generally an incomplete modified model domain knowledge model (2) and is designed mainly to anticipate users' behavior for its interpretation. The ideal user model must make accurate predictions of the behavior of any user in any domain context. For example, a set of possible responses to a block of data from the system.

With the user model's concept a diagnostic process is often associated - adapting the user model based on the data obtained through usersystem dialog. In automated learning systems prior progress checks' results for particular students can be used - providing information regarding learning course segments work should be currently focused on.

Interaction script determines which piece of data and at what time will be transmitted to the user. In the most general case the interaction script is not hard coded and is derived based on the current situation and the deduction method, stored as a set of principles or rules. The adaptation is based on predicting users' responses, generated by user models, users' real reaction and relations between the workflow episodes stored in the domain model.

Interaction scripts may vary in relation to the degree of «freedom» given to the user, and can range between two extremities: full control of all user actions and guiding users through workflow episodes workflow - or complete freedom of user's navigational activity and giving requests-based recommendations.

Fig. 4 illustrates relationship between these four basic concepts of knowledge communication.

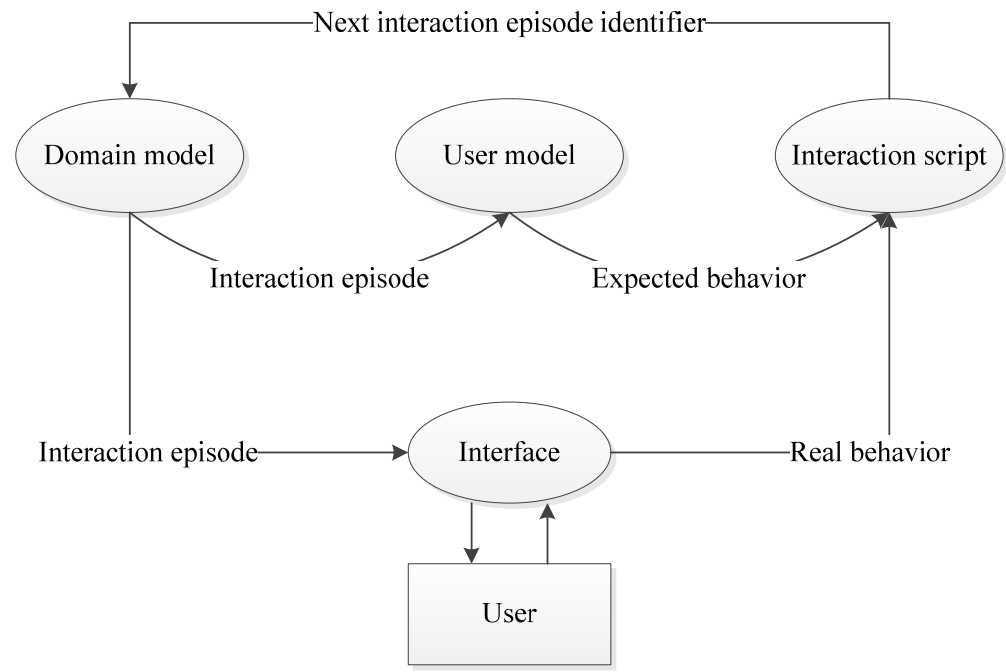

Fig. 4. Basic concepts of knowledge communication systems 
User system interaction's script construction and modification takes into account the interaction script, based on the users' model and their actual behavior when processing previous information blocks taken from the domain model.

Conclusion. By using models of user interface, users' cognitive portraits, domain and users' knowledge is it possible to perform flexible adaptation and personalization of user-systems interface. Such adaptation involves modifying not only data presentation, but also data storage and he script of the interaction itself based on the workflow specifics and the users' preferences. This results in fewer mistakes when perceiving and processing information and lower stress levels for the users. When used in the learning process, such adaptation and personalization allow to improve both testing and studying efficiency for each particular student.

\section{References:}

1. Furtat Yu. O. Functional basis of means of the automated systems' user interfaces' adaptation to the user's cognitive characteristics / Yu. O. Furtat // Mathematical and computer modelling. Series: Technical sciences / Scientific digest of V. M. Glushkov Institute of Cybernetics of the National Academy of Sciences of Ukraine and Kamianets-Podilskyi National Ivan Ohiienko University. - Kamianets-Podilskyi : Kamianets-Podilskyi National Ivan Ohiienko University, 2013. - Iss. 8. - P. 120-131.

2. Gadezka Z. M. Development of object-oriented models of visual attention / Z. M. Gadezka, V. A. Nagornii, I. A. Zhiriakova // Proceedings of International Scientific Conference «Modern management in production and humanitarian activity», 5-6th of April, 2005. - Cherkassy : East-European University of Economics and Management, 2005. - P. 39.

3. Us M. F. Onthological approaches to evaluation of the listener's cognitive level in conditions of «electronic» education / M. F. Us, Z. M. Gadezka, P. A. El-Murr // Modeling and informational technologies. Scientific digest of Pukhov Institute for Modelling in Energy Engineering. — Kyiv, 2006. - Iss. 38. — P. 150-155.

\section{ПОБУДОВА КОРИСТУВАЦЬКОГО ІНТЕРФЕЙСУ І МОДЕЛІ ПРЕДМЕТНОЇ ОБЛАСТІ 3 ВРАХУВАННЯМ КОГНІТИВНИХ ХАРАКТЕРИСТИК КОРИСТУВАЧА І ОСОБЛИВОСТЕЙ РОБОЧОГО ПРОЦЕСУ}

Для автоматизованих систем розглядаються принципи побудови i управління користувацьким інтерфейсом (відповідає за форму представлення даних користувачу) та моделі предметної області (відповідає за структуру представлення даних користувачу) як складових комплексу засобів управління взаємодією користувача 3 автоматизованою системою, адаптації цієї взаємодії до персональних характеристик користувача та особливостей робочого процесу.

Ключові слова: інформачійна взаємодія, адаптація, модель предметної області, когнітивні харакеристики користувача.

Отримано: 21.11.2018 